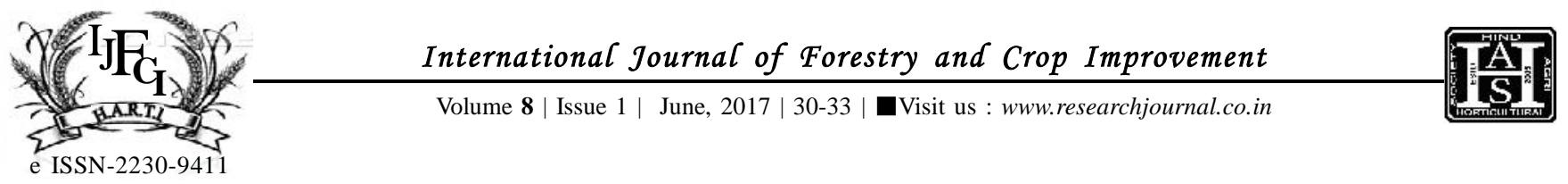

\title{
Growth and productivity of Melia dubia under different plant density
}

\author{
H.Y. PATIL, G. KaRATANGi KiRANKUMAR AND S.M. MutANAL
}

\begin{abstract}
Different density experiment was conducted to know the effect on growth and productivity of Melia dubia. The trial was laid out with different spacing regimen as per statistical design. The growth observations were recorded at different intervals of time viz., 42, 45, 48 and 51 months after planting. The results revealed significant difference among different planting densities and maximum was recorded in planting density of 714 trees/ha $(46.85 \mathrm{~cm}, 10.59 \mathrm{~m} ; 50.14 \mathrm{~cm}, 10.99 \mathrm{~m} ; 52.99 \mathrm{~cm}, 11.22 \mathrm{~m}$ and $55.76 \mathrm{~cm}, 11.43 \mathrm{~m})$ for both girth $(\mathrm{cm})$ and height $(\mathrm{m})$, respectively for all the time interval. However, the total stand volume $\left(\mathrm{m}^{3} / \mathrm{ha}\right)$ in all the time interval was significantly superior in case of planting density of 2500 trees/ha $\left(125.00 \mathrm{~m}^{3} / \mathrm{ha}, 148.33 \mathrm{~m} / \mathrm{ha}^{3}, 165.83 \mathrm{~m} /\right.$ ha and $189.25 \mathrm{~m}^{3} / \mathrm{ha}$ ). Based on the results of the present experiment it is concluded that, the planting density of 2500 trees/ha exhibited significant stand volume compare to other planting density. These findings have significant relevance to get maximum productivity under monoculture block plantation system.
\end{abstract}

KEY WORDS : Girth, Height, Volume, Spacing, Planting density

How TO CITE THIS ARTICLE : Patil, H.Y., Karatangi Kirankumar, G. and Mutanal, S.M. (2017). Growth and productivity of Melia dubia under different plant density. Internat. J. Forestry \& Crop Improv., 8 (1) : 30-33, DOI: 10.15740/HAS/IJFCI/8.1/30-33.

Article Chronical : Received : 08.02.2017; Revised : 01.05.2017; Accepted : 13.05.2017 